\title{
Religious Dress and the Making of Women Preachers in Australia, 1880-1934
}

Kerrie Handasyde

University of Divinity

\begin{abstract}
What women preachers wore was a source of fascination for the press who regularly reported on their attire and decorum, as if respectable dress might mitigate the transgression that was a woman's preaching. For women, however, putting on religious dress represented the putting on of a right to minister and to speak: a making of the self anew. This article examines a range of late nineteenth- and twentieth-century reports in mainstream media and denominational journals for what they reveal about the relationship between women's clothing and the representation of gender and religious authority. Building on the work of feminist historians on media representations of women preachers, the article brings a number of previously unexamined sources into view. With an awareness of Protestantism's historical privileging of speaking and listening over seeing, the article finds that denominational approaches to visual culture in general, and women's dress in particular, influenced the reception of women's ministry.
\end{abstract}

When Chave Collisson fronted the media to promote Maude Royden's 1928 preaching tour of Australia, she exhorted critics not to approach 'the women's movement as that washing-day feeling ... but as the best-frock-day feeling'. ${ }^{1}$ Royden would be wearing 'charming clothes', Collisson assured reporters, for women preachers represented a new, yet recognisably feminine expression of religiosity and professionalism. Her response addressed the reality that women's preaching constituted a modern spectacle; a performative act in which gendered identity,

1 'Maude Royden, Welcome Plans', Sun, 14 February 1928, 19. 
and religious authority, was styled and ritualised. ${ }^{2}$ They could appear neither drab and dour nor overtly sexual for, despite centuries in which Protestantism privileged speaking and hearing the Word of God over the visual spectacle of the Catholic mass, women preachers knew that they were watched (objectified, monitored, minded) as often as they were heard.

This article examines reporting on women preachers' dress in mainstream media and denominational presses in the late nineteenth and early twentieth centuries in three Protestant denominations: The Salvation Army, the Presbyterian Church and the Churches of Christ in Australia. The sources, many new to scholarship, are read with an eye to both visual culture and the socio-religious role of dress in each denominational context. Historians have made connections between the authorisation of women's ministry and factors such as patterns in church governance, theological constructions of priest and pastor, education of women, biblical liberalism and church women's guilds. ${ }^{3}$ However, this article observes new aspects of the relationship between visual culture and women's religious authority in Australia that are important in the story of the reception of women as preachers and, more generally, in the social control of women.

Women's dress has long been recognised as a tool of social control in religious communities. The church as the Body of Christ effectively monitored and contained the bodies of women by maintaining expectations around acceptably modest dress. With conformity to dress codes (some denomination-specific, and some demurely conservative variations on the cultural mainstream) came social inclusion and the internalising of religious and social assumptions around gender and behaviour. ${ }^{4}$ Liberation, if a 'calling' that was so closely monitored can be named as liberation, would require a new dress for a new way of appearing in public and before the Body of Christ. For women officers in The Salvation Army,

2 Liz Conor, The Spectacular Modern Woman: Feminine Visibility in the 1920s (Bloomington: Indiana University Press, 2004), 7, doi.org/10.7202/018846ar; Judith Butler, 'Performative Acts and Gender Constitution: An Essay in Phenomenology and Feminist Theory', Theatre Journal, 40, no. 4 (1988): 519-20, doi.org/10.2307/3207893.

3 For example, Julia Pitman and Peter Bentley, 'Women Ministers Before 1977: An Update', Church Heritage, 21, no. 1 (2019): 23.

4 For example, Beth Graybill and Linda B Arthur, 'The Social Control of Women's Bodies in Two Mennonite Communities', in Religion, Dress and the Body, ed. Linda B Arthur (Oxford: Berg, 1999), 9, doi.org/10.2752/9781847888839/reldrbody0006; Joan Kendall, 'The Development of a Distinctive Form of Quaker Dress', Costume, 19, no. 1 (1985): 58-74, doi.org/10.1179/cos.1985.19.1.58; and, on Mormon dress, Colleen McDannell, Material Christianity: Religion and Popular Culture in America (New Haven: Yale University Press, 1995), 198-221, doi.org/10.2307/3170490. 
their public ministry meant the adoption of a military-style uniform; for Presbyterian deaconesses, ministry came with a neat blue dress with white collar and cuffs; and, for the first woman minister in Churches of Christ, a denomination where uniforms and clerical dress were disapproved of, preaching combined with a sartorial inventiveness that confounded the church into watchful silence.

Each of these denominations understood ministry as a role that was pastoral (or shepherding) rather than priestly, thus removing the significant barrier to women's ordination that the theology of a mediating priesthood presented. In denominations such as Anglicanism, the priest mediated Christ to the people through his own body. Thus, it was argued, seeing as Christ was a man, he must be mediated through and represented in the body of a man. While Protestant churches with a pastoral understanding of ministry did not face this issue of the need for women to bodily represent Christ, they inferred prohibitions on women's preaching from scripture. Carefully chosen verses from the New Testament defended preaching as the prerogative of men, and silence as that of women. ${ }^{5}$ Needless to say, they did not pay great heed to those New Testament verses in which Phoebe, Priscilla and Junia lead the churches, or Philip's four unmarried daughters prophesied. ${ }^{6}$

Despite broad nineteenth-century consensus that scripture barred women from preaching, churches that prized the individual experience of salvation (especially those in the Holiness tradition, which includes Methodist, Salvation Army and Pentecostal churches) found that some women's preaching could be countenanced as a special gift of God through the Holy Spirit. For women in the Pentecostal movement, authority came through personal encounter with the Holy Spirit. For instance, after experiencing Holy Spirit baptism, Sarah Jane Lancaster established her own church in North Melbourne in 1909, the first Pentecostal church in Australia. ${ }^{7}$ Mediation of the Holy Spirit through the body of a woman meant that women could act not under their own authority, but as conduits of the

\footnotetext{
5 For example, 1 Corinthians 14:34-35; 1 Timothy 2:12.

6 Romans 16:1-7; Acts 21:8-9.

7 Shurlee Swain, 'Lancaster, Sarah Jane', The Encyclopedia of Women and Leadership in Twentieth Century Australia, Australian Women's Archive Project (2014), www.womenaustralia.info/leaders/biogs/ WLE0330b.htm; Kerrie Handasyde, 'Mother, Preacher, Press: Women Ministers and the Negotiation of Authority, 1910-1933', in Contemporary Feminist Theologies: Power, Authority, Love, eds. Kerrie Handasyde, Cathryn McKinney and Rebekah Pryor (Abingdon: Routledge, forthcoming).
} 
Spirit. Two millennia of Christian women have attributed their ministries to the actions of the Spirit through them: early twentieth-century Pentecostal women operated within a long tradition of prophetesses and mystics.

In churches that valued reason and pragmatism over experience, formal women's organisations offered a platform from which women could speak in public on moral and spiritual matters, and agitate for social and legislative change. ${ }^{8}$ In the late nineteenth to mid-twentieth centuries, women in mainline traditions formed Christian organisations including the Young Women's Christian Association, Anglican Mothers' Union, Presbyterian Women's Missionary Union and Woman's Christian Temperance Union, which campaigned not only against liquor but in favour of suffrage. A number of women active in suffrage campaigning moved from the town square soap-box to the church pulpit in the years after women achieved the vote. Maude Royden was among them. ${ }^{9}$ Chave Collisson's publicity for Royden's Australian preaching tour reveals the negotiations required of these women around received notions of femininity and religious authority in changing times.

As feminist scholars have observed-especially Shurlee Swain, Laura Rademaker and Diane Winston-what women wore when preaching was reported in the press with great interest. ${ }^{10}$ The role of dress in the establishment of women's Christian identity is well established in sociological studies, but in historical studies it is more often noted in the historiography of mission where religious conversion is signalled by the culturally problematic adoption of colonial styles of dress along with

8 Ellen Warne, Agitate, Educate, Organise, Legislate: Protestant Women's Social Action in Post-Suffrage Australia (Melbourne: Melbourne University Publishing, 2017).

9 Jacqueline R de Vries, 'Transforming the Pulpit: Preaching and Prophecy in the British Women's Suffrage Movement', in Women Preachers and Prophets through Two Millennia of Christianity, eds. Beverley Mayne Kienzle and Pamela J Walker (Berkeley: University of California Press, 1998), 318, doi.org/10.1525/9780520919273-020.

10 Shurlee Swain, 'In These Days of Female Evangelists and Hallelujah Lasses: Women Preachers and the Redefinition of Gender Roles in the Churches in Late Nineteenth-Century Australia', Journal of Religious History, 26, no. 1 (2002): 65-77, doi.org/10.1111/1467-9809.00142; Laura Rademaker, 'Religion for the Modern Girl: Maude Royden in Australia, 1928', Australian Feminist Studies, 31, no. 89 (2016): 336-54, doi.org/10.1080/08164649.2016.1254024; Diane Winston, Red-Hot and Righteous: The Urban Religion of The Salvation Army (Cambridge, MA: Harvard University Press, 1999), 17, doi.org/10.1086/ahr/105.4.1323. 
colonial expressions of Christianity. ${ }^{11}$ Dress has rarely been a concern of denominational historians who have tended to frame discussion of women's preaching within the machinations of internal church politics and belief. ${ }^{12}$ Smaller so-called unorthodox denominations, even those in which women held leadership roles, are particularly under-represented in major works of scholarship on women preachers. ${ }^{13}$ As Frank Bongiorno has noted, religious unorthodoxy has been neglected in Australian historiography, and this matters given that many women found their political voice in idealistic minority religious groups. ${ }^{14}$ They found their religious voice there too, as this article shows.

For women finding their voice as preachers, appearing mattered also. What to wear was a constant concern as dress represented to the congregation and to the world the woman's embodiment of the community's gendered moral codes and, thus, her moral and spiritual standing before God. ${ }^{15}$ In the discussion to follow, published writings about women preachers in The Salvation Army, the Presbyterian Church and Churches of Christ reveal that the relationship between dress and each denomination's reception of visual culture played a significant part in the authorisation of ministry.

11 For example, Pamela E Klassen, 'The Robes of Womanhood: Dress and Authenticity Among African American Methodist Women in the Nineteenth Century', Religion and American Culture: A Journal of Interpretation, 14, no. 1 (2004): 57, doi.org/10.1525/rac.2004.14.1.39; Deborah Gaitskell, 'Power in Prayer and Service: Women's Christian Organizations', in Christianity in South Africa: A Political, Social, and Cultural History, eds. Richard Elphick and Rodney Davenport (Berkeley: University of California Press, 1997), 257-8, 264, doi.org/10.1353/jsh.2000.0009; Elisha P Renne, 'Cloth and Conversion: Yoruba Textiles and Ecclesiastical Dress', in Undressing Religion: Commitment and Conversion from a Cross-Cultural Perspective, ed. Linda B Arthur (Oxford: Berg, 2000), doi.org/10.2752/9781847888938/undrel0006.

12 For example, Ken Newton, 'The Status and Role of Women in Australian [Brethren] Assemblies', Christian Brethren Review, 41 (1990); Sally Kennedy, Faith and Feminism: Catholic Women's Struggles for Self-Expression (Sydney: Studies in the Christian Movement, 1985).

13 For example, Anne O'Brien, God's Willing Workers: Women and Religion in Australia (Sydney: UNSW Press, 2005); Muriel Porter, Women in the Church: The Great Ordination Debate in Australia (Melbourne: Penguin, 1989). A Churches of Christ historian was prompted to write in response to Porter's omission of women in ministry in churches with differing understandings of ordination: William Tabbernee, 'Women and Pastoral Ministry in Churches of Christ', Digest of the Australian Churches of Christ Historical Society, 103 (1989).

14 Frank Bongiorno, 'In This World and the Next: Political Modernity and Unorthodox Religion in Australia, 1880-1930', ACH: The Journal of History and Culture in Australia, 25 (2006): 180, 191-4.

15 Klassen, 'The Robes of Womanhood', 40-2. 


\section{The Salvation Army and 'All Her Daring'}

When Captains Thomas and Adelaide Sutherland disembarked the Aconcagua to lead The Salvation Army in South Australia in 1881, she wore a plain dark dress and bonnet and he wore a military-style uniform with a brass helmet. ${ }^{16}$ It was only three years since The Salvation Army had changed its name from the East London Christian Mission and rejected its Methodist inheritance-clerical dress, sacraments and ecclesial language — in favour of a new narrative. ${ }^{17}$ Adopting a military metaphor that reflected the mission's battle for souls, The Salvation Army named its periodical The War Cry, prayers were known as knee-drills, congregations called army corps, street preaching termed 'firing a volley', and members were assigned military rank and military costumes. They expected heartfelt conversion (born out of direct experience of the divine and expressed in the emotive language of the heart that was characteristic of the Holiness Movement) and publicly represented their new-found salvation with the putting on of new clothes. These new uniforms were an outward manifestation of the narrative in which the members lived. The men's uniforms were, at first, a ragtag collection of cast-offs from the British army. They adopted an existing wardrobe and an existing metaphor for men's vocation. But there were no women in the British army, no castoffs to be had. Women Salvationists sewed their own uniforms, literally crafting a new self in preparation for initiation into a new life.

Uniforms provided Salvationist women with a new way of being in public. The dark blue dresses and bonnets signalled modesty, yet attracted attention to the cause. ${ }^{18}$ Women Salvationists in uniform were intended to be noticed in the streets and in the press-visual spectacle was integral

16 Barbara Bolton, Booth's Drum: The Salvation Army in Australia 1880-1980 (Sydney: Hodder and Stoughton, 1980), 13.

17 Roger J Green, The Life and Ministry of William Booth, Founder of The Salvation Army (Nashville: Abingdon Press, 2005), 30; Pamela J Walker, Pulling the Devil's Kingdom Down: The Salvation Army in Victorian Britain (London: University of California Press, 2001), 1, doi.org/10.3138/cjh.37.1.170. Military metaphors were popular in Victorian England, as witnessed in the proliferation of children's 'brigades' and missionary organisations such as the Anglican 'Church Army', carrying connotations of obedience, self-sacrifice and empire.

18 Lynne Marks, "The "Hallelujah Lasses": Working-Class Women in The Salvation Army in English Canada, 1882-92', in Gender Conflicts: New Essays in Women's History, eds. Franca Iacovetta and Mariana Valverde (Toronto: University of Toronto Press, 1992), 67-117, doi. org/10.3138/9781442675186-005. 
to the denomination's missionary strategy. ${ }^{19}$ Their uniforms authorised women to speak and to act for the transformation of lives. ${ }^{20}$ Significantly, they re-defined what was possible for women in the evangelical tradition. Four months after her arrival in Australia, missionary and preacher Captain Adelaide Sutherland was profiled in South Australia's Christian Colonist in terms that re-framed evangelical Christian femininity:

Far from manifesting a want of feminine feeling, there was a real charm about all her daring, yet she was ever ready for a charge straight over hedge or ditch to save. Nobody who saw her clamber over the seats of the Hall of Varieties at Newcastle to seize some penitent, but hesitating ruffian by the head or neck, and lead him out to the penitent form for salvation, can forget the emotion of admiration for her fervour and straight-forward, honest dealing with souls. ${ }^{21}$

Along with the women's Salvation Army uniform came a new vocabulary: fighting qualities could be ascribed to women missionaries in the cities.

In early Australian editions of The War Cry, women officers are profiled with words to fit their military-style clothes. Adjutant Cartner of Launceston, pictured in uniform, was described as 'True as steel ... a champion of God'. ${ }^{22}$ Ensign Sparks of Auckland would reportedly 'face men or devils in the interests of the fallen' ${ }^{23}$ Ensign Winter of Adelaide was 'especially adapted for ... uplifting the fallen and building them up to take their place once more in the battle of life' ${ }^{24}$ In uniform, these women were recast, re-born into a new rhetorical world of salvation soldiery. They were authorised to preach and to take part in the battle for souls in city streets. As Salvation Army co-founder Catherine Booth argued, mild-mannered 'effeteness' and concern with 'respectability' and 'reputation' hindered the saving of souls - what the world needed was 'Aggressive Christianity'. ${ }^{25}$

19 Kerrie Handasyde, God in the Landscape: Themes in the Literary History of Australian Protestant Dissent (London: Bloomsbury Academic, forthcoming).

20 For discussion of perceptions of women's ministry, see Shurlee Swain, Constructing the Good Christian Woman (Melbourne: Uniting Church Historical Society, 1993), 3-10; Anne O'Brien, God's Willing Workers: Women and Religion in Australia (Sydney: UNSW Press, 2005), 36-49, 100.

21 War Cry (British edition, issue number not cited) quoted in 'Mrs Sutherland', Christian Colonist, 1 July $1881,2$.

22 War Cry, 30 July 1898.

23 War Cry, 27 August 1898.

24 War Cry, 13 August 1898.

25 Catherine Booth, Papers on Aggressive Christianity (London: The Salvation Army, 1891), 'The Holy Ghost' 14, 'The World's Need' 12, 'Aggressive Christianity' 3. 
The battle was not only metaphorical but literal, as Salvationist street preachers were often attacked. The War Cry regularly ran lists of injuries, including bruises, concussions, lacerations and even the deaths of women officers. Such lists represented the Salvationists' embodied approach to evangelisation, to the upturning of social values, and to their perception of themselves as martyrs for the cause. ${ }^{26}$ Wearing the uniform, Mary Ann Cox proved a 'fiery, eloquent preacher' whose words provoked attack from a gang of youths to try to wrest the Salvation Army flag from her in Sydney's Domain. Reportedly 'wrapping it round herself and defying the mob to take it', she made herself anew, embodying The Salvation Army like a robed Britannia. ${ }^{27}$ Virtue joined with 'daring' in the new dress of Salvationists such as Mary Ann Cox and Adelaide Sutherland. ${ }^{28}$

Women from other denominations, especially Methodists and other churches influenced by the Holiness Movement with its emphasis on personal conversion, were drawn to The Salvation Army because of the opportunities it offered. Real equality between the sexes was in fact elusive, despite reports that 'the females seem to hold equal rank' (both Thomas and Adelaide Sutherland were afforded the rank of captain). ${ }^{29}$ However, women could preach and take on public ministries traditionally considered the province of men. Catherine Booth had long been an advocate of women's preaching, having published her Female Ministry: Or, Woman's Right to Preach the Gospel in 1859 in support of American Methodist and Holiness Movement preacher Phoebe Palmer, who came to Britain that year. Booth argued that much of the resistance to women's preaching resulted from a perception that ambition was 'unfeminine':

There seems to be a great deal of unnecessary fear of women occupying any position which involves publicity, lest she should be rendered unfeminine by the indulgence of ambition or vanity; but why should woman any more than man be charged with ambition when impelled to use her talents for the good of her race. ${ }^{30}$

26 War Cry (n.d.), cited in Bolton, Booth's Drum, 72. This tendency was also noted in 'The Salvation Army,' Kapunda Herald, 23 April 1886.

27 'How Army Flag Was Saved' (obituary for Mary Ann Sanders, née Cox) News, 26 November $1932,5$.

28 War Cry (British edition, n.d.) quoted in 'Mrs Sutherland', Christian Colonist, 1 July 1881, 2. Mary Ann Cox reportedly converted to The Salvation Army shortly before the Sutherlands were sent to South Australia, and was known at her death as the first woman member and officer of the Salvation Army in Australia': 'How Army Flag Was Saved', News, 26 November 1932, 5.

29 'The Salvation Army', South Australian Advertiser, 27 July 1881, 5.

30 Catherine Booth, Female Ministry: Or, Woman's Right to Preach the Gospel (London: Morgan and Chase, 1859), 4. 
Women's public preaching was endorsed by Catherine Booth and practised from the beginnings of The Salvation Army, and the uniform protected against accusations of vanity and pride.

The Army's insistence on a plain dark blue dress and bonnet required that women give up any outward sign of wealth or class or worldly ambition. In this way they would embody a way of living that empowered even as it invited mockery of their dressing up in pseudo-military costume. Women could wear no silk, no bustle, no jewels and no embroidery beyond the Army's insignia. ${ }^{31}$ This required a public rejection of accepted norms of femininity. ${ }^{32}$ It was a rejection that became part of the religious conversion narrative for many women in many denominations. As historian Diana Winston notes, a genre of writing developed within North American Salvation Army publications in which women hesitated to wear the dark, plain uniform for reasons of fashion. ${ }^{33}$ But then, in these conversion stories, Salvationists come to accept the uniform as they accepted a life in Christ. In the absence of the sacraments of baptism and Eucharist, it functioned something like an 'outward sign of an inward grace'. ${ }^{34}$

The correlation of costume with conversion is evident in the mainstream Australian press too. In 1890 the Seymour Express described a woman who 'had been a notorious character', but who had since 'donned the uniform, and [become] one of the most useful workers'. ${ }^{35}$ In 1897 the Bowral Free Press reported an officer's testimony that once she and her sister had 'got saved. My next impulse was to wear the army uniform'. ${ }^{36}$ The uniform came with an identity that subsumed all else. In Salvation Army weddings women did not wear bridal gowns but were married in uniform, often adding a white bridal sash. ${ }^{37}$ At death, officers were buried in uniform and coffins were draped with the Army's flag and the deceased's poke bonnet. ${ }^{38}$ In the vibrant visual culture of The Salvation Army, the uniform represented eternal salvation.

31 Winston, Red-Hot and Righteous, 86.

32 Lewis R Rambo, Understanding Religious Conversion (New Haven: Yale University Press, 1993),

33 Winston, Red-Hot and Righteous, 88-9.

34 Definition of sacrament commonly attributed to St Augustine.

35 Seymour Express, 5 December 1890, 2.

36 Bowral Free Press, 8 September 1897.

37 Evening News, 14 August 1899; Tasmanian, 26 November 1892.

38 Evening News, 20 February 1891. 
There was only one other costume that could better represent a woman Salvation Army officer's commitment to Christian ministry. The Salvation Army reported on its women officers' imprisonment as an indication of their great commitment to ministry, and it published staged photographs of women wearing prison garb as witness. ${ }^{39}$ In the 1880s and 1890s, the Salvation Army's noisy processions and preaching provoked opposition from the public, especially from publicans and their customers who were frequent targets of Salvationist evangelism. ${ }^{40}$ By-laws were introduced to limit street preaching and arrests were made. In 1891 when the Ballarat city council introduced by-laws to prevent the Army from marching, Salvationists were compelled by force of their own fighting and persecution narratives to court arrest under those laws. A group of officers, both women and men, was tried before the court. Then another group, and then another who travelled from Melbourne especially for the purpose. ${ }^{41}$ Refusing to pay fines, they were sent, with some hesitation on the part of the judge, to Ballarat Gaol. If the young officers thought themselves actors in a drama of sin and salvation, they had chosen an especially powerful stage on which to perform. This gaol was not a country lock-up but a high security prison in which three men were publicly executed that year, one of them for killing a cellmate. ${ }^{42}$

The newspapers reported that the Salvationists were not housed with other prisoners, but they were made to take off their uniforms and wear prison clothes. ${ }^{43}$ The authorities presumably hoped that such a loss might weaken the Salvationists' identity and resolve. Certainly, newspapers recognised the significance of the loss of that which made them so recognisable in the streets. The Argus noted that the Salvationists 'submitted quietly' to wearing prison dress. ${ }^{44}$ Their humble obedience to prison demands appeared as meekness to civil authorities, but in The Salvation Army's alternative worldview, submission to prison authorities was an act in emulation of Christ who 'humbled himself, and became obedient unto death, even the death of the cross' ${ }^{45}$ In the light of Holiness theology, if the uniform signalled salvation, prison clothes functioned as a sign of complete sanctification: a 'being made like Christ' who likewise suffered

39 Handasyde, God in the Landscape.

40 Bolton, Booth's Drum, 71, 76-80.

41 Age, 2 March 1892.

42 Ballarat Star, 21 April 1891, 2.

43 'The Salvation Army and the Ballarat City Council', Argus, 13 October 1891, 5.

44 Ibid., 5.

45 Philippians 2:8 (King James Version). 
at the hands of the authorities and the mob. ${ }^{46}$ Costume became part of the narrative of Salvationist incarceration. ${ }^{47}$ Joseph Perry, who ran the Salvationist's Prison-gate ministry, took pictures for The Army's press. The published image looks highly staged, but The Salvation Army understood well the power of clothing in the public performance of ministry.

\section{Presbyterian Deaconesses, 'Always Neat and Trim'}

For women ministering as deaconesses in the Presbyterian Church, both prison garb and garments designed for publicity would have been unthinkable. Indeed, when badges were introduced for deaconesses to wear while working with the poor in Melbourne streets, the women found they attracted attention and insult, and requested that they not be made to wear them. ${ }^{48}$ Instead, from 1898 , they wore a uniform of blue dress with white collar and cuffs that was intended to be a 'simple, but distinctive costume for protection and for recognition', but which was, in fact, somewhat anonymous in the absence of insignia or other distinguishing features. ${ }^{49}$ While the sources are silent on the matter, perhaps the deaconesses sought to avoid public confusion with the badges and blue dresses of rowdy, street preaching Salvationist women. Certainly, the Presbyterian Church in Victoria valued restraint and propriety, carrying with it to the colonies the establishment assumptions of the Church of Scotland, which were sustained, in part, by the wealth and influence of Scottish pastoral families in the western district. When the young Victorian women of the Deaconess Training Institute wore their blue-and-white dresses, they put on the colours of Scotland and publicly subscribed to the church's gendered expectations around restraint and propriety. In nineteenth-century Britain, Presbyterian women were initially assessed for missionary service on the basis of 'ladylike' qualities,

46 One of the accused, William Bowes was released against his will after his mother, who evidently did not ascribe to the extreme end of Holiness Movement theology, paid the fine: Bendigo Independent, 3 March 1892.

47 Report about the officers in the photo says they were 'clothed in prison garb': 'Salvation Army Troubles at Ballarat', Argus, 24 February 1892, 7.

48 Minutes of Executive Committee of the (Deaconess) Training Institute, East Melbourne, (n.d.), quoted in Catherine L Ritchie, Not to Be Ministered Unto: The Story of Presbyterian Deaconesses Trained in Melbourne (Melbourne: Uniting Education, Uniting Church in Australia's Synod of Victoria, 1998), 14 .

49 Minutes of Executive Committee of the (Deaconess) Training Institute, East Melbourne, 2 May 1898, quoted in Ritchie, Not to Be Ministered Unto, 14. 
while men were chosen for their education and leadership experience. ${ }^{50}$ Although the need for women's training was quickly recognised, being 'ladylike' persisted as a requirement. Women applying to the Deaconess Training Institute in Melbourne were asked to provide a character reference 'from a lady' and answer questions as to whether they could sing, or speak a second language. ${ }^{51}$ The missionary advantage of French or Latin in the streets of Melbourne would have been minimal, but languages suggested refinement.

The Institute's advertising leaflet reminded applicants of the New Testament example of Phoebe who was called 'not to rule' but to engage in 'helpful service'..$^{2}$ The particular interpretation of Phoebe's work and the blue dresses echoed the pronouncement of John Knox, sixteenthcentury Presbyterian founder, that women's garments are a witness to their weakness and inability 'to execute the office of men', insisting that women's rule was 'repugnant to Nature', 'the subversion of good Order'. ${ }^{53}$ Dress made known women's natural subordination, according to Knox. While both Presbyterian deaconesses and Salvationist women wore blue dresses, their costumes carried very different expectations around gender and religious authority. The Presbyterians' 'Blue Ladies' were a world apart from the 'daring' women officers of The Salvation Army and Catherine Booth's 'Aggressive Christianity..$^{54}$

Presbyterian deaconesses performed similar duties to those of women officers in The Salvation Army, especially in their ministry to the poor and ill and in their missionary evangelism, and some occasionally preached from the pulpit. However, the deaconesses represented decorum and social status even as they laboured to help the lowly. They were 'set apart' for ministry as deaconesses. ${ }^{55}$ This separation was evident in their

50 Rhonda Anne Semple, Missionary Women: Gender, Professionalism and the Victorian Ideal of Christian Mission (Woodbridge: Boydell and Brewer, Boydell Press), 192, doi.org/10.1086/ ahr/110.1.225.

51 'Rules of Applicants' (1898), quoted in Ritchie, Not to Be Ministered Unto, 12-13.

52 'Our Deaconesses and the Training Institute' (leaflet, c. 1898), quoted in Ritchie, Not to Be Ministered Unto, 10.

53 John Knox, 'First Blast of the Trumpet against the Monstrous Regiment of Women' (1558), quoted in Jane Dawson, John Knox (New Haven: Yale University Press, 2016), 142-3. Knox's injunction was aimed at least in part at the rule of Mary Tudor, but his pronouncements against ostentation in women's dress and the inadmissibility of women to leadership have proved powerful and persistent.

54 Booth, 'Aggressive Christianity'.

55 Commission of Assembly (May 1895), quoted in Ritchie, Not to Be Ministered Unto, 34. 
dresses that were 'always neat and trim'. ${ }^{56}$ Advertising for women to join the 'Blue Ladies', a 1930 article for The Missionary Chronicle describes them 'going into big State schools, being welcomed and escorted in by dirty little children, their spotless cuffs smeared by hot, loving hands'. They are seen visiting all manner of places a 'Lady' would never venture except as a deaconess working with women and children: factories, courts, a Chinese school, homes for unmarried mothers, pawnshops and 'waiting outside the gaol'. ${ }^{57}$ In all these places, the 'Blue Ladies' remained clean and respectable.

Significantly, the recruitment advertisement noted that a 'Blue Lady' could also be found 'preaching on Sunday in a little church' [emphasis added], although 'that Blue Lady had lost her smile!' In this depiction, another 'setting apart' is evident: while ministry among the poor required a smile, preaching the gospel was much more serious work. It was so serious that women were not ordained to the Ministry of the Word and the Sacraments in the Presbyterian Church in Australia until 1974 and, in the conservative remnant of Presbyterianism that remained outside the Uniting Church at union, no women have been ordained since $1991 .{ }^{58}$

Preaching by deaconesses was not common prior to the 1970s. When they did preach, it was most often as a guest speaker associated with a special church service organised by the Presbyterian Women's Missionary Union. ${ }^{59}$ Miss Hilda Wilson's ministry to the St Andrew's Presbyterian Church in remote Queenstown, Tasmania, was a rare exception. In 1952, '[o]wing to the acute shortage of clergy', Deaconess Wilson was ritually 'Set Apart' to 'do all the work normally carried out by a clergyman', including preaching and performing marriages (requiring a licence) and burials. ${ }^{60}$ Her remarkable circumstances led to an article in Melbourne's Age newspaper, where she is pictured smiling in her blue dress and white collar. Despite being 'Set Apart' by the church and licensed by the state, Hilda Wilson did not wear the garb of a clergyman but that of a deaconess: respectable and subordinate.

56 Advertisement to become a 'Blue Lady', Missionary Chronicle, June 1930, quoted in Ritchie, Not to Be Ministered Unto, 71-3.

57 Ibid., 71-3.

58 Porter, Women in the Church, 32.

59 'Church Budget - Presbyterian', Morwell Advertiser, 6 May 1954, 13.

60 'Deaconess to be "Set Apart", Mercury, 19 January 1952, 7; 'Presbyterian Deaconess Performs Marriages', Age, 25 October 1952, 14. 


\section{Churches of Christ and the Ambiguity of 'Sunday Best'}

Like Deaconess Wilson, the appointment of Violet Callanan to the ministry of the Church of Christ in Hawthorne, Queensland, was attributed to a dearth of suitable men. In the Churches of Christ there was no ritual of 'setting apart' as the denomination did not practise ordination. Instead, it professed the 'priesthood of all believers', denying any distinction between clergy and laity in the administration of the sacraments and preaching of the Word. ${ }^{61}$ Accordingly, preachers wore no clerical garb, no robes or vestments, but neat 'Sunday best'. A simple jacket and tie was expected. Ostentation was considered a sign of sin and so people dressed modestly for worship services in plain chapels with clear windows and only the words of scripture adorning the walls.

Despite their historical adherence to lay ministry, by the 1920s almost all Churches of Christ congregations employed men to preach. Paying their ministers with the often meagre proceeds of the congregation's offering bowl, no central ecclesial body had the right to oversee ministry appointments. When the 36 members of the Church of Christ at Hawthorne, Queensland, could not attract a minister, they quietly engaged the services of a young woman with a Foreign Missions Certificate instead. Violet Callanan was Hawthorne's minister from 1931 to 1934, the first woman in pastoral ministry in Churches of Christ in Australia.

Callanan studied for her Foreign Missions Certificate alongside men training for ministry-the denomination's College of the Bible only enrolled women for studies in missionary service. ${ }^{62}$ Annual college photographs show rows of men in ties, with women seated at the front, their heads covered in accordance with 1 Corinthians 11:2-6. The women wear hats and skirts with blouses and cardigans, but, like the men training for ministry of the Word, Violet Callanan wears a collared shirt and tie. ${ }^{63}$ It was a sign of things to come; her 'calling' to ministry and to the wearing of jackets and ties. Despite her serious attire, members of

61 Ordination was introduced in 1941: Graeme L Chapman, One Lord, One Faith, One Baptism: A History of Churches of Christ in Australia, 2nd ed. (Melbourne: Vital Publications, 1989), 144.

62 Kerrie Handasyde, 'Editorial', Historical Digest of the Australian Churches of Christ Historical Society, 177 (2012): 3.

63 Photo of 'Students at Glen Iris, 1928' and of students enrolled in Foreign Mission studies (College of the Bible, Glen Iris, Melbourne 1928), Australian Churches of Christ Archives, Mulgrave, Vic. 
the congregation joked about having a 'petticoat ministry', ${ }^{64}$ for no matter what she wore on top, as a woman in a man's job she was defined by her metonymic underwear.

Words mattered in Churches of Christ, but Callanan was barely spoken of in the denomination's press. The Church of Christ at Hawthorne kept news of her appointment quiet. In 1931, when Callanan's role began, women's preaching was in the national news: the Reverend Winifred Kiek, wearing the black gown of Congregationalist preachers, was engaged in a high-profile ordained ministry in Adelaide; and Methodist lay preacher Doreen Rita Allen, in her black undergraduate gown, demonstrated women's abilities in the pulpit as the Methodist Church debated the ordination of women in synods around Australia. ${ }^{65}$ The Churches of Christ's federal periodical reported on the news of Methodist debates, but made no mention of Callanan's ministry for many months. ${ }^{66}$ After nearly a year, Callanan's ministry was noted for the first time and simply as a local matter: a column with news from various churches says that at Hawthorne, 'Miss Callanan's addresses much appreciated'. ${ }^{67}$ In 1932 the Churches of Christ annual Conference Program mentions that 'Miss Callanan has been acceptably assisting Hawthorne Church' [emphasis added].${ }^{68}$ She presented herself as a minister in a tie and collared shirt, but the denomination viewed her as an assistant, a help meet to the church, just as in Genesis 2:18 where a woman was created in order to be a help meet to a man. Churches of Christ's organisation of locally autonomous congregations allowed for diverse beliefs, but major disagreements could put the denomination's continuing association at risk. Fracture was always possible and so controversy was avoided. The revolutionary nature of Callanan's role was confined as a local matter, undertaken with little public recognition and muted language.

The congregation grew under Violet Callanan and in such circumstances a minister might be expected to stay on or to move to a larger church. But Callanan did not go on to another pastoral ministry. Instead, she

64 '80th anniversary of Hawthorne Church of Christ' (Brisbane, 1994), 9. Queensland archival sources kindly supplied by Jonathan Smith, Queensland Churches of Christ Archives.

65 Julia Pitman, 'Prophets and Priests: Congregational Women in Australia, 1919-1977'

(PhD thesis, University of Adelaide, 2005), 240. For scholarship on Doreen Rita Allen and Winifred Kiek see Handasyde, 'Mother, Preacher, Press'.

66 HG Payne, 'News of the Churches: Queensland News-letter', Australian Christian, 28 April 1932.

67 'News from the Churches: Hawthorne', Australian Christian, 25 August 1932.

68 'Churches of Christ Annual State Conference Programme' (Queensland, 1932), 12. 
took a position with the church's social welfare department in Melbourne. After the minimal mention of her work at Hawthorne and no celebration of her status as the first woman minister, the church's national periodical reported enthusiastically on her new appointment: 'Miss Callanan has the distinction of being the first woman to be set aside for special social work'. ${ }^{69}$ She was to fulfil a role akin to that of Presbyterian deaconess, working among women and children in need. She put aside her collar and tie and adopted a new uniform of her own devising. It was a grey tunic with a veil, something like a nun's habit; she would be known as 'Sister'. Perhaps these clothes would bring her authority as they did women in other traditions. But the negative comments she received were overwhelming and she stopped wearing her self-styled habit. ${ }^{70}$ When she returned to Queensland to visit family and friends it was reported in the denominational press that she would also 'relate her experiences as Social Service Sister' to the congregation at Ann Street Church of Christ in Brisbane. ${ }^{71}$ No mention was made of her congregational ministry. Callanan's story of men's ties and nun's habits is not a narrative of passing: it is not about disguise, or playfulness, or the determination to live another life. ${ }^{72}$ This is about a woman who was equipped and chosen for ministry but whose female body, however she dressed it, lacked authority within the worshipping community. Whatever she wore, in the subdued visual culture of Churches of Christ there was no recognition for the preaching ministry of Violet Callanan.

\section{Dressing the Part}

Press reports on women preachers reveal that, in Protestant churches where women preachers were watched as often as they were heard, dress and denominational reception of visual culture mattered in the authorisation of women's ministry. The Salvation Army used its press and the richly visual imaginative world of Salvation soldiery to redefine femininity in fighting terms. The putting on of a Salvation Army uniform

69 Australian Christian, 17 May 1934.

70 Tabbernee, 'Women and Pastoral Ministry in Churches of Christ', 3.

71 'Visit of Sister Violet', Christian Echo (Queensland Churches of Christ), May 1937, 4.

72 For example, Lucy Chesser, "Woman in a Suit of Male": Sexuality, Race and the Woman Worker in Male "Disguise"', 1890-1920', Australian Feminist Studies, 23, no. 56 (2008): 175-94, doi.org/10.1080/08164640701576074; Valerie Smith, 'Class and Gender in Narratives of Passing', in Feminist Consequences: Theory for the New Century, eds. Elisabeth Bronfen and Misha Kavka (New York: Columbia University Press, 2001), 189-210, doi.org/10.7312/bron11704-008. 
was a sign of conversion to a new life and a new way of being, and a valuable source of publicity for the mission-oriented denomination. Presbyterian deaconesses were clothed in respectability for work that was lowly. Inconspicuous without insignia, yet 'set apart', a blue dress signalled that Hilda Wilson's role in Queenstown remained a secondorder ministry despite her responsibilities. Women's uniforms, as part of the visual culture of these two denominations, simultaneously expanded and circumscribed the religious authority of women preachers. However, an absence of clerical robes and a prohibition on ostentation in dress effectively limited religious imagination and, with it, the visualisation of expanded roles for women. In Churches of Christ, where clothing officially played no part in ministry, Violet Callanan wore a collar and tie, then a tunic and veil. Neither brought her recognition. In a denomination that was fundamentally suspicious of visual culture, her attempts to re-style herself as a preacher of the Word were largely met with silence. Factors that favoured women's ministry-locally autonomous church governance (or a strongly supportive hierarchy), pastoral understandings of ministry, education, biblical liberalism and strong women's guilds-were not enough to enable women's ministry. Women needed the opportunity to 'appear' as a preacher and, in appearing, become a preacher. 
This text is taken from Lilith: A Feminist History Journal: Number 26, published 2020 by ANU Press, The Australian National University,

Canberra, Australia.

doi.org/10.22459/LFHJ.26.05 